\title{
Lumen
}

Selected Proceedings from the Canadian Society for Eighteenth-Century Studies

\section{Slavery, Revolution and Political Strategy: Lessons from the International Campaign to Abolish the Slave Trade}

\section{James Dybikowski}

Volume 13, 1994

URI : https://id.erudit.org/iderudit/1012524ar

DOI : https://doi.org/10.7202/1012524ar

Aller au sommaire du numéro

Éditeur(s)

Canadian Society for Eighteenth-Century Studies / Société canadienne d'étude du dix-huitième siècle

ISSN

1209-3696 (imprimé)

1927-8284 (numérique)

Découvrir la revue

Citer cet article

Dybikowski, J. (1994). Slavery, Revolution and Political Strategy: Lessons from the International Campaign to Abolish the Slave Trade. Lumen, 13, 87-98.

https://doi.org/10.7202/1012524ar 


\section{Slavery, Revolution and Political Strategy: Lessons from the International Campaign to Abolish the Slave Trade}

Early in 1788, Jacques Brissot founded a society in Paris which later became known as the Amis des Noirs. It was modeled after the London Committee for the abolition of the slave trade. The campaign to abolish the slave trade was international in scope. If pressure was to be successfully applied on the nations which participated in the trade, collaboration between national advocacy groups was essential. But while the London Committee and the Amis des Noirs were similar in some respects and their relations were very close and cordial for some time, there were also striking differences in the way they defined their objectives, their organization, their political context and the way in which they responded to it, and the ability or determination of their leadership to make the most of their opportunities.

Although international collaboration held great promise, it also could make their task more difficult, especially when it cut across powerful nationalistic and revolutionary (or anti-revolutionary) programs. The differences and relations between the two groups raise important issues with obvious contemporary relevance. How narrowly should organizations define their institutional goals? What role should the prospects for success have in this process of definition? How close should their collaboration be? What impact can differences in organizational strength have on the prospects for successful collaboration? The account in this paper considers the light that the relations between the London Committee and the Amis des Noirs casts on these questions.

$* * * * *$

James Phillips, Quaker publisher and founding member of the London Committee, wrote to his friend Brissot in February 1793, immediately after France had declared war on Britain: 'Remember that the cause of the Africans was the beginning of thy political career. - I am not afraid of thy deserting it - but the best of us stand in need of an occasional 
spur to our duty. I know your situation is perilous \& calls for your utmost exertions. Yet there is room for attention to this subject \& you should never forget the inconsistency of a nation permitting such traffick in men who are risquing their existence to procure liberty for themselves. ${ }^{1}$ Phillips's immediate purpose was to persuade Brissot to use his influence to protect the vulnerable fledgling settlement in Sierra Leone and its vessels from attack. Opponents of the slave trade commonly viewed the existence of a flourishing establishment on the coast of Africa as key for the success of their campaign, and Brissot had for some time taken an interest in it. ${ }^{2}$

Phillips was never backward about reminding Brissot of what duty demanded. At the start of the revolution, he upbraided him on hearing from him that he "had laid aside the prosecution of the Blacks being wholly taken up with your own liberties \& the arrangement of your municipal governments. ${ }^{3}$ The tension felt by many French abolitionists during the Revolution between pressing their campaign to end the slave trade, on the one hand, and securing the nation's constitution and its economic stability, on the other, surfaced more than once. Early in 1790, for example, Condorçet took issue with Brissot whose priorities at the time were ordered more to Phillips's liking. He argued that it would be imprudent in France's circumstances to press vigorously for abolition. ${ }^{4}$ Such a campaign would divide the nation when its basic structures were vulnerable. The National Assembly, he shrewdly added, was weak on colonial issues, and abolitionists would be targeted if trouble erupted between colonists and blacks. ${ }^{5}$ Phillips, for his part, believed that no more favorable opportunity for achieving abolition was likely to arise. France's constitutional objectives, he argued, could scarcely be achieved by assigning to abolition a lower priority. He added in his February 1793, letter: 'The Cause of the Blacks is so intimately connected with the general cause of liberty that they cannot be disjoined even in idea.'

The friendship between Phillips and Brissot was long-standing and close. Soon after Brissot learned of the founding of the London Committee in 1787, he wrote to Phillips to ask him to secure his appointment as its Paris agent. ${ }^{6}$ At the time, Brissot was preoccupied with both slavery and the slave trade. His Examen critique, published in 1786, incorporated a defense of blacks and a call for the abolition of slavery. In 1787, at a meeting of the Société Gallo-Americain, co-founded by him to encourage the development of a correspondence and trade between America and France, he gave notice that he would introduce a plan to abolish slavery at a forthcoming meeting. ${ }^{7}$ In another work from the same period, he forecast that Europeans, shamed by their participation in the slave trade, would soon act to end it. ${ }^{8}$ 
The Société Gallo-Americain, like so many of Brissot's visionary projects, would collapse, but his approach to the London Committee was the event which Phillips characterized as the start of his political career. The London Committee actively encouraged international cooperation to abolish the slave trade. Its president, Granville Sharp, wrote to Brissot soon after he made his initial approach to the Committee: 'having embarked in this cause not simply as Englishmen but as Citizens of the World... we consider our plan as extending to the whole world and shall not be compleated till these flagrant violations of the rights of mankind universally cease. ${ }^{9}$ The Committee believed that if France joined England in abolishing the trade, others would inevitably follow. ${ }^{10}$ It was an argument with considerable appeal for reformers on both sides of the channel. Mirabeau, whose Analyse des papiers anglois became the organ for French abolitionists before the Revolution, wrote enthusiastically to Brissot about the desirability of establishing 'une coalition des philanthropes François et des philanthropes Anglois. ${ }^{11}$ Brissot needed no convincing.

William Wilberforce was equally impressed by the argument for international cooperation. He was aware that his opponents would argue that if Britain withdrew from the trade, France would fill the vacuum at the cost of Britain's maritime hegemony. With Pitt's blessing, he enlisted William Eden to approach the French government to sound out its willingness to make a conditional commitment to abolish the slave trade if Parliament were to support abolition. ${ }^{12}$ Indeed, Wilberforce hoped at this time to secure a general European accord 'before the question is at all start'd in Parlt. \& I am laboring to keep a number of people quiet in London \& elsewhere, who are extremely humane \& extremely imprudent... our application would be much more likely to be successful if you could hold out to us a favorable prospect of what you can do for us in the country of France \& Spain. ${ }^{13}$ He observed that the remarkable growth in the influence of the London Committee on public opinion might convince the French government of the changing temper of the times. ${ }^{14}$

The French government, however, was unmoved. It feared that if it conditionally promised to abolish the slave trade and Parliament balked, it would expose itself to irresistible pressure to honor its commitment unilaterally. Wilberforce considered traveling to France to put his case directly, but was persuaded not to do so. ${ }^{15}$ He was forced to defend his position in Parliament without any prior assurance that France would follow suit, but he continued to consider ways for enlisting active French cooperation, although, by the time of the Revolution, he no longer favored an international treaty as the vehicle for achieving abolition. He became convinced that the negotiation would be used as a delaying tactic 
and would undermine the political credibility of other strategies for achieving the desired end. ${ }^{16}$

While the London Committee promoted international collaboration, it also wanted to maintain its organizational distance from other groups and was not keen to foster the kind of links Brissot proposed to it. It responded coldly to his proposal that he should act as its Paris agent and collect subscriptions in France on its behalf. Instead it encouraged him to form an independent committee to promote the abolition of the slave trade. ${ }^{17}$ It cited the very different conditions in France in justification of its decision.

What Brissot wanted primarily, however, was formal recognition and he readily agreed to the London Committee's proposal. In his organizing efforts, he consistently emphasized that he acted at the London Committee's request and he promised to make his society as like it as possible. After he successfully formed the Paris Society, he drew attention to the advantages of close liaison between the two groups on objectives and modes of proceeding. He even advocated formal affiliation between them. ${ }^{18}$ At one stage early in the Revolution, the Amis des Noirs hoped to persuade the London Committee to circulate a petition to be presented to the National Assembly. Phillips responded coldly: 'It is certainly a new scheme for the subjects of one country to petition the legislature of another \& we cannot perceive any ground for hope of its being attended with any good. ${ }^{19}$ The London Committee was blunter. Such an action would be regarded as 'officious and unwelcome interference. ${ }^{20}$

Although the London Committee resisted attempts to unify the two groups, the ties were close and, for a time, very much so. Until 1791 the London Committee invariably noted the progress of the Amis des Noirs in its periodic reports. ${ }^{21}$ It translated and arranged for the publication of some of its brochures. ${ }^{22}$ The Amis des Noirs returned the compliment. At this stage the achievements of the one group were viewed as highly useful vehicles by the other for advancing its case. Later their close relations would be exploited by their enemies to embarrass them both.

The members of the London Committee were passionately opposed to slavery as well as to the slave trade. The Quaker, Joseph Woods, for example, had earlier argued for the immediate abolition of the slave trade and the gradual emancipation of slaves. ${ }^{23}$ The London Committee, however, deliberately narrowed its scope to abolition and resolved to take no position on emancipation. On this fundamental issue, it did not waver.

Woods explained to an American correspondent that the Committee adopted this policy because the abolition of slavery was a long term objective at best '\& possibly cannot originate here without interfering with the legislative rights of the colonies. ${ }^{24}$ Clarkson, recollecting the 
debate at the London Committee, remarked: 'It appeared... to be the sense of the committee, that to aim at the removal of both would be to aim at too much, and that by doing this we might lose all. ${ }^{25} \mathrm{He}$ later argued more aggressively to a French correspondent: 'We are of opinion that the Emancipation of the Slaves would be of no benefit to them at present, would ruin some of their proprietors, would endanger the revenue for a time and would be an Evil rather than a Good. ${ }^{26}$ He aimed to convince the public, including planters who relied on slavery, not only of the immorality, but equally of the impolicy of the slave trade. ${ }^{27}$ Separating abolition from emancipation made his position more plausible.

This deliberate narrowing of focus to the slave trade was crucial, if the London Committee was to function effectively as a tightly organized, limited-membership ginger group, acting in close support of the parliamentary effort to abolish the slave trade. Its organizational backbone was a group of Quakers with considerable experience petitioning Parliament on slavery and the slave trade. ${ }^{28}$ They and the London Committee to which they belonged, however, were constitutionally conservative unlike some other extra-parliamentary political organizations established at the time. Their aim was to make the existing political structure function for their cause, not to change or threaten it.

The Amis des Noirs, whether at the time of its founding before the Revolution or after its outbreak, functioned in a different political context, although, after the Revolution, it attempted - albeit unsuccessfully - to adapt the parliamentary tactics which had been so successfully used in Britain in the National Assembly. ${ }^{29}$ Its constitution did not reflect a wish to imitate the tight structure of the London Committee. Nor was its leadership, and Brissot very notably, tempted to accept the principle of constitutional conservatism as a constraint on its position.

The critical difference between the two groups, however, was the way they defined their objectives. For, despite Brissot's pronouncements about imitating the London Committee, he committed the Amis des Noirs from the outset to long-term emancipation. ${ }^{30}$ Brissot went farther and carelessly implied that the London Committee shared the same goal. $^{31}$

This difference in objectives was reflected in a difference in style of argument. Clarkson, writing for the London Committee, essentially limited himself to utilitarian arguments which relied on his extensive knowledge of how the slave trade functioned. Brissot, on the other hand, derived his position directly from abstract philosophical principles of liberty and equality. ${ }^{32}$ His stance made it difficult for the Amis des Noirs to retreat to more limited objectives when it later wished to focus exclusively on the slave trade. 
The Adresse à l'assemblée nationale, pour l'abolition de la Traite des Noirs of January 1790, which attempted to persuade the National Assembly to form a committee to investigate the slave trade, tried to blunt the force of this commitment to emancipation. In it Brissot claimed that emancipation was not the purpose of the Amis des Noirs. ${ }^{33} \mathrm{He}$ was trying to refocus the objective of the Amis des Noirs on the abolition of the slave trade and, at the same time, to blunt the relentless attacks against it, which, as in England, focused on emancipation. In light of its policy statements, the Amis des Noirs was not well placed to defend itself against such attacks.

Other more stylistic differences between the London Committee and the Amis des Noirs are reflected in personal differences between Brissot and Clarkson, although they did not prevent each from holding the other in the highest personal regard. ${ }^{34}$ Clarkson was intellectually cautious, careful not to claim more than he could justify on the available evidence. He was clear, if didactic, thorough in his research, personally at ease in a variety of social worlds, with impeccable integrity, courageous, and single-minded. He had considerable leadership ability and he was imaginative about devising strategies for advancing his cause. In Paris, he, not the Amis des Noirs, enjoyed free access to Necker and through him to the King. Again, he, not the Amis des Noirs, thoroughly interviewed Geoffrey de Villeneuve, a French officer who accompanied the Swedish explorer and visionary C.B. Wadstrom a few years earlier to Senegal and who had a highly detailed knowledge of the French slave trade. Clarkson transcribed and published Villeneuve's evidence. ${ }^{35}$

Brissot, while not wanting courage, was mercurial. He relied on rhetoric and his immense, if scattered energy. He was constantly in financial trouble, proposing grandiose projects he had no reasonable hope of carrying out. His optimism consistently led him to overestimate the prospects for success, and while Clarkson shared this optimism, it did not lead him, by contrast, to leave any stone unturned to enhance the prospects for success. ${ }^{36}$ Brissot's background on the fringes of the illegal book trade, moreover, made him personally vulnerable and his publications on the slave trade progressively became exercises in self-justification.

Until the Revolution, it would have been rational to anticipate that Britain would abolish the slave trade before France. The London Committee was very successful in influencing public opinion through its publications, its research, and its organizational energy. It had powerful parliamentary friends. It was also well-funded in its early years. The Amis des Noirs tried to emulate it, but public opinion was not as advanced in France. Despite the personal distinction of many of its 
supporters, it was constantly short of money; its independent research effort was unimpressive; and its organization was weak.

The Revolution, however, reversed these expectations. Clarkson's motive for going to France was to assist the Amis des Noirs to press for abolition in the dramatically changed political circumstances. Revolutionary France, as he saw it, was under an obligation to act even without commitments from other nations to follow its example. The scope of its Declaration of the Rights of Man could not be limited to metropolitan France, but he stopped short of drawing the emancipationist conclusions to which this argument inevitably led. As knowledge of the Revolution and its principles spread, the only choices for France would be either to abolish the slave trade and improve conditions for slaves, or face rebellion. ${ }^{37}$ Success in France, he believed, would place great political pressure on Parliament to act likewise.

When Clarkson arrived in Paris, he was warmly greeted. Le Patriote François noted that he had come to cement the ties between the London Committee and the Amis des Noirs and, more significantly, to give the latter's efforts a boost with whatever assistance he could offer, financial included. ${ }^{38}$ Clarkson soon observed, however, that the meetings of the Amis des Noirs were held irregularly, that they were infiltrated by slave owning interests and that they were desperately short of funds to mount an effective campaign to place the slave trade on the National Assembly's agenda. ${ }^{39}$ He decided to work independently of it, but in collaboration with some of its leading members.

Clarkson was a forceful presence in France. This fact clearly reflected the leadership and organizational weakness of Brissot and the Amis des Noirs. It is inconceivable that a French abolitionist would have enjoyed a comparable standing in Britain. Unsurprisingly, Clarkson and the London Committee became, with the Amis des Noirs, targets of furious attack by proponents of the slave trade. ${ }^{40}$ His life was threatened, and the Amis des Noirs, through its liaison with him and the London Committee, was pictured as the dupe of a British plan to undermine French interests. ${ }^{41}$ International collaboration had a tough time standing up to the powerful forces of nationalism and economic anxiety effectively exploited by the enemies of abolition. Brissot later wrote to Clarkson in his broken English that abolitionists 'must avoid to give fresh \& apparent opportunities to their [enemies'] calumnies. ${ }^{42}$ By the time he wrote, however, their enemies in France already had as many opportunities as they needed.

Back then to our original questions. How narrowly should organizational objectives be trimmed and how important are the prospects of success in deciding on them? In the circumstances of the campaign against the slave trade, the London Committee clearly marked out much 
the better strategic position and organizational structure while managing to do so without serious compromise to the beliefs of its members about the evil of slavery. The Amis des Noirs, despite its protestations, did not follow its example, whether deliberately or, more likely, from a failure to appreciate the reasoning which motivated its British cousin. It became the prisoner of its original position and soon found itself, in consequence, on the political defensive.

Or, again, how close should the cooperation between national groups be, particularly when such collaboration is easily representable as cutting across powerful nationalistic or revolutionary (or anti-revolutionary) programmes? Here important tactical errors were made by both groups, and notably by Clarkson and Brissot. While the opposition was prepared to exploit any openings, there can be no doubt but that Clarkson's incautious and very public offers of financial support for the Amis des Noirs as well as his prominent leadership role in France supplied hostages to fortune. Clarkson did not display the kind of political sensitivity to possible French reactions to his role as he showed, for example, in rejecting the request to circulate a petition in Britain for presentation in France. When Brissot made his original approach to the London Committee in 1787, the Committee showed a caution which it subsequently overcame, but with little benefit in the realization of its purposes. From 1791 onwards, it ceased to go out of its way to advertise how close its relations to the Amis des Noirs were or, more significantly, had been. ${ }^{43}$

\section{JAMES DYBIKOWSKI}

University of British Columbia

\section{Notes}

1 Archives Nationales (AN), AF II/45/348/45, Phillips to Brissot, 8 February 1793; a copy with a later postscript listing the colony's ships, 348/46; draft copy, Library of the Friends Historical Society, London (FHS), Thompson-Clarkson Albums (T-C) II/35.

2 See, for example, FHS, T-C II/41, C.B. Wadstrom (who wished to establish a Swedenborgian colony 'far from all unworthy designs \& infestations of the Europeans') to Henry Gandy, Bristol, 16 September 1788. For Brissot's interest, see A critical examination of the Marquis de Chatellux's travels (Philadelphia: Joseph James, 1788), 62; St. Johns College, Cambridge (SJC), Antislavery Box 1, Brissot to Clarkson, 9 March 1790; 29 March 1790; 27 May 1790; Historical Society of Pennsylvania (HSP), PSPAS, 2-152, Brissot to Myers Fisher, 20 June 1790.

3 AN, 446AP6, Phillips to Brissot, 9 September 1789. 
4 AN, 446AP7, Condorçet to Brissot, undated. See also Clarkson, History of the abolition of the slave trade (London: Longman, Hurst, Rees and Orme, 1808), ii.139-43.

5 Brissot's numerous letters to Clarkson in the first half of 1790 at SIC show him consistently underestimating the strength of the opposition.

6 British Library (BL), Add. MS. 21254/13, shows that Brissot's original letter was dated 18 August 1787. This letter does not survive, but a follow-up does at FHS, T-C II /115, Brissot to Phillips, 8 September 1787. Leonore Loft ('Quakers, Brissot and Abolitionists,' Journal of the Friends' historical society 55 (1989), 279) implies that the initiative for establishing the Paris Committee dates from Brissot's trip to London in 1787 when he was allegedly invited to attend meetings of the London Committee. Her account is of a piece with Brissot's memoirs (M.F. de Montrol (ed.), Mémoires de Brissot (Paris: Ladvocat, 1828-32), ii.2), but the correspondence cited above shows that the events leading to the founding of the Paris society were quite different. In February 1788, the Marquis de Lafayette made an independent approach to the London Committee (BL, Add. MS. 21254/38).

7 C. Perroud (ed.), J.-P. Brissot, Correspondence et papiers (Paris: Picard \& Fils, [1912]), 135.

8 Brissot and E. Clavière, Considerations on the relative situation of France, and the United States of America (London: Logographic Press, 1788), 305.

9 Gloucestershire County Record Office (GCRO), Hardwicke Court Papers (HC), Box 28, Packet L, Sharp to Brissot, 29 February 1788.

10 GCRO, HC, Box 28, Packet L, Sharp to Lafayette, 29 February 1788. See also BL, Add. MS. 21254/38, 12 February 1788, for the London Committee's resolution 'that a society for the same purposes as our own will be instituted in France so that if the governments both of Great Britain and France should really prohibit the infamous traffick in their respective dominions, the humane example may probably be followed by other European nations'; BL, Add. MS. 21255/3-4, 5 March 1788, for its appointment of a committee to collect materials to be translated into a variety of languages 'being sensible that the arguments in [the slave trade's] favour founded in a competition of supposed national interests will be removed by the reformation becoming general.'

11 AN, 446AP8, Mirabeau to Brissot, 15 January 1788.

12 Journal and correspondence of William, Lord Auckland (London: Richard Bentley, 1861), i.239-40.

13 BL, Add. MS. 34427/121, Wilberforce to Eden, 23 November 1787. If Brissot was not already aware of these secret negotiations, he was made aware of them by Abbé Girod in January 1788 (AN, 446AP4, Abbé Girod to Brissot, 21 January 1788). Such an accord was supported by the Amis des Noirs (Amis), Réglemens de la société des amis des noirs, $10 ; 14$.

14 BL, Add. MS. 34427/401, Wilberforce to Eden, 18 January 1788.

15 Bodleian Library (BodL), MS. Wilberforce, d. 17/9, Grenville to Wilberforce, 18 December 1787.

16 Wilberforce, like Brissot, argued that unilateral abolition would exert enormous pressure on the French to follow suit (Speech of William Wilberforce on the question of the abolition of the slave trade (London: J. Walker, C. Stalker and W. Richardson), 44-47). In 1789 Wilberforce was about to go to France when parliamentary 
business and political uncertainty there led him to change his mind (BodL, MS. Wilberforce, Diary, b. 2, 9 July 1789). During the Peace of Amiens he proposed joint action by both nations to Grégoire. Grégoire regretted that he was not sufficiently influential to act in concert with him (Mémoires de Grégoire (Paris: Ambroise Dupont, 1837), i.398). For his views against a negotiated treaty at the time of the Revolution, see R. and S. Wilberforce, The Life of William Wilberforce (London: J. Murray, 1838), i.231.

17 BL, Add. MS. 21254/13; Analyse des papiers anglois, I, 475-76. Analyse dated the letter conveying the resolutions of the London Committee 4 November 1788 rather than 4 September 1788 by confusing Quaker with French dating conventions. Brissot and Clavière accepted the London Committee's proposal in a letter of 13 October 1788 (BL, Add. MS. 21254/17; original at SJC).

18 C. Perroud, Correspondance et papiers, 166-71, Brissot to the London Committee, 19 March 1788. The minutes of the London Committee, however, do not indicate that it received this letter.

19 AN, 446AP6, Phillips to Brissot, 9 September 1789.

20 GCRO, HC, Box 54, Committee to Brissot, 24 September 1789. See also Clarkson, History, ii.125-26. On the other hand, the London Committee lobbied Necker directly. After Brissot attended a meeting of the London Committee early in 1789, Samuel Hoare wrote: 'Our Friend M. de Warville, on his Return from America, spent a little time here; and being now in France, we trust will, by his personal Exertions, be a means of quickening those of his countrymen. During the last autumn, we addressed their Minister of Finance, Mons. Necker. His answer, tho' very friendly and polite, has not removed our Apprehensions that the Progress of this good work in that, and in other maritime Nations of Europe, will require Time, and the exercise of Patience' (HSP, PSPAS, Loose correspondence, I-246, Samuel Hoare to the Pennsylvania Society for promoting the Abolition of Slavery, 3 March 1789).

21 See BL, Add. MS. 21254/29, for the first mention in the report of 15 January 1788, as the Amis was about to be established. BL, Add. MS. 21256/20-1, 26 April 1791, is the first report in which it was not mentioned.

22 See, for example, The Diary, or Woodfall's register, 28 August 1789; 20 April 1790.

23 [Joseph Woods], Thoughts on the slavery of the negroes (London: James Phillips, 1784). His position was of a piece with the petition of the British Quakers to Parliament. See also The Case of our fellow-creatures, the oppressed Africans (London: James Phillips, 1783).

24 HSP, Matthews MS., Woods to Wm. Matthews, 28 January 1788.

25 Brissot, History, i.284.

26 Huntington Library (HL), CN 53, Clarkson to Bouvet, 1 December 1789.

27 In a letter to PSPAS, Granville Sharp remarked: 'And this just representation of ourselves and our views, we thought it our duty, not long since, to lay before the public, in answer to the often-repeated charge, that our endeavours went not only to abolition, but emancipation; an imputation of little consequence to us, individually considered, but big with mischief to the cause, in which we are engaged' (American museum IV (1788), 509). The Amis printed a statement from the London Committee answering such charges in Analyse des papiers anglois, ii.320. 
28 The Quakers have been rightly identified by historians as perhaps the earliest and certainly one of the most effective prototypes for extra-parliamentary political organization in Britain. See N. C. Hunt, Two early political associations (Oxford: Clarendon Press, 1961).

29 See Brissot's letters to Clarkson at SJC, and what survives of Clarkson's correspondence to Brissot at AN, 446AP6. Earlier parliamentary debates were reported in detail by Analyse des papiers anglois.

30 As a later statement of its position trenchantly put it: 'Les noirs ne sont pas encore mûrs pour la liberté: il faut les y preparer: tel est la doctrine de cette société' (Le Patriote François, 24 August 1789). See also Journal de Paris, 14 December 1789 where the principles of the Amis are stated as (i) all men are free and equal in rights; (ii) the slave trade ought to be abolished; (iii) after abolition, slavery ought to be ended.

31 Brissot, Discours sur la necessité d'établir à Paris une société pour concourir, avec celle de Londres, à l'abolition de la traite $\mathcal{E}$ de l'esclavage des negres, 12; A critical examination, 57 . The Amis originally referred to itself as a society to abolish the slave trade and slavery. See, for example, HSP, PSPAS, I-129; Analyse des papiers anglois, ii.409.

32 Brissot Discours, 4, which follows the argument of A critical examination, 53. Phillips, in a set of proposed corrections of $A$ critical examination, distanced himself from both principles (see AN, 446AP6, Phillips to Brissot, n.d.). In his earlier On the slavery and commerce of the human species (London: James Phillips, 1787), ii.3, which considered, as its title implies, slavery as well as the slave trade, Clarkson committed himself to the view that liberty is a natural right of human beings, but he argued his case rather differently in works he prepared for the use of the London Committee, while not disavowing his earlier position. Brissot's style of argument in writing for the Amis, by contrast, carried over from his earlier works.

33 He immediately undermined his claim, however, when he added that the society did not advocate the immediate freeing of slaves.

34 For Clarkson's tribute to Brissot, History, ii.165-66; for Brissot's to Clarkson, Montrol, Mémoires de Brissot, iii.2-6.

35 Clarkson employed an agent to go to Havre de Grace to obtain documents relating to the French slave trade. Brissot (New travels in the United States (London: J.J. Jordan, 1794), 67) acknowledged his debt to the London Committee for information on the mechanism used by English traders to claim French bounties.

36 This overestimation is obvious in the series of letters Brissot sent to Clarkson in 1790 at SJC.

$37 \mathrm{HL}, \mathrm{CN} 53$, Clarkson to Bouvet.

38 Le Patriote François, 24 August 1789.

39 Clarkson, History, ii.133. On spies and defections, see also SJC, Brissot to Clarkson, 27 May 1790. The details of Clarkson's financial authority are set out in Boston Public Library, MS. Acc. 493, Clarkson to Phillips, endorsed 21 December 1789. See also Clarkson, Strictures on a life of Wilberforce, 72-73; R. and S. Wilberforce, The Life of William Wilberforce (London: J. Murray, 1838), i.229. After Clarkson left Paris, Brissot continued to write about the desperate financial situation of the Amis. He received some help as a result of these appeals from 
Clarkson and his friends. See SJC, Brissot to Clarkson, 29 March 1790; 25 April 1790; 27 May 1790; Le Page to Clarkson, 29 March 1790; AN, 446AP6, undated letter from Brissot, evidently to Clarkson. See also C. Perroud (ed.), Lettres de Madame Roland (Paris: Imprimerie Nationale, 1900-2), ii.276-77, Madame Roland to Bancal, 12 May 1791.

40 Mémoires de Grégoire, i.389-98, estimated that Brissot, Pétion and Condorçet were attacked in 5 to 600 published libels.

41 William Dyllwyn (HSP, PSPAS, 2-33, extract, 8 October 1789) described how Clarkson was 'several times openly threatened with assassination; and he told the persons that if such was their fixed purpose, he would give them the opportunity, as he was satisfied their effecting it, would instantly seal the destruction of the wicked Traffic \& practice which they meant to support'. See Clarkson, History, ii.128-31. Lanthenas' M. Lamiral réfuté par lui-même, $44 \mathrm{ff}$, summarizes the charges of a British conspiracy. One sample is in Journal de Paris, 28 December 1789, 'Lettre de M. Mosneron à M. le Marquis de Condorçet'. L'Argus patriote 1, no. 8, 220-1; no. 11, 269; Replique de Charles Theveneau de Morande à Jacques-Pierre Brissot (Paris: chez Froullé, 1791), 66, all comment adversely on Brissot's relation to Clarkson. See the extract from Brissot's Réponse à tous les libelistes printed in Le Patriote François, 18 August 1791, in which, despite his protestations about the propriety of maintaining a correspondence with Clarkson, he oddly concedes that he had not received a letter from Clarkson over the past eighteen months. Although he complained that he had not recently heard from Clarkson at $\mathrm{BL}$, Add. MS. 41170/108, Brissot to Phillips, 26 October 1790, he referred to recent letters from him in several letters in SJC, and most recently to a letter of 4 May 1790, in Brissot to Clarkson, 27 May 1790. Those letters fall within the 18-month period in which he claimed not to have heard from him.

42 AN, 446AP6, undated and unaddressed draft from Brissot to Clarkson.

43 From that time the relations between the London Committee and the Amis became more occasional than they had been. There are fewer references to their correspondence in the London Committee's minute books, and a letter at SJC, Lanthenas to Clarkson, 16 January 1792, explains that members of the Amis had been distracted by other political issues and that there had not been enough constancy of organizational attention within the society to prevent a steady stream of defections. I owe thanks to Martin Fitzpatrick and Paul Russell for helpful suggestions on an earlier draft. 